Original Research Paper

\title{
Explorasi Mikroba Beraroma dari Bahan Alam
}

\section{Prapti Sedijani $^{* *}$, Dewa Ayu Citra Rasmi ${ }^{1}$, Syamsul Bahri ${ }^{1}$}

${ }^{1}$ Program Studi Pendidikan Biologi Fakultas Keguruan dan Ilmu Pendidikan Universitas Mataram, Indonesia;

\author{
Article history \\ Received: October $16^{\text {th }} 2018$ \\ Revised: January $18^{\text {th }} 2019$ \\ Accepted: March 14 ${ }^{\text {th }} 2019$ \\ *Prapti Sedijani: Program \\ Studi Pendidikan Biologi \\ Fakultas Keguruan dan Ilmu \\ Pendidikan Universitas \\ Mataram, Indonesia; \\ Email: \\ praptisedijani@unram.ac.id.com
}

\begin{abstract}
The Scented volatile compound has a huge market as its wide applications in daily life. The extraction of this compound from natural resources produces a very low rendement. Microbes synthesize secondary metabolit might resemble of their host have been explored from scented natural resources (flowers: Damask rose, Jasminum sambac and Plumeria acutifolia); cymbopogon, muntinga calabura L and leave of Panadus amaryllis). It was found 12 bacterial and 14 fungal scented isolates that were various in terms of scent types and intensities. They were bread starters like the smell, alcohol like the smell, sweet sugar like the smell, salaka like the smell and fresh sugarcane juice like smell. Several isolates emit original host like the smell in very low intensities. Persistency scent test showed that the scents were persistently emitted when cultured on PDA medium.
\end{abstract}

Key Words: Scented volatile; Damask rose; microba; exsplorasi

Abstrak: Minyak atsiri mempunyai pangsa pasar yang sangat besar karena manfaatnya yang luas dalam kehidupan sehari-hari. Ekstraksi minyak atsiri langsung dari bahan alam menghasilkan rendement yang sangat rendah. Mikroba mensintesis metabolit secunder yang mirip dengan inangnya telah dieksplorasi dari beberapa bahan alam (bunga: mawar, melati dan Plumria acutifolia); batang sereh, buah kersen dan daun pandan wangi. Sebanyak 12 isolat baketri dan 14 jamur yang mengemisikan aroma sedap/positif dengan jenis dan intensitas emisi bervariasi. Adapun aroma yang diemisikan adalah aroma seperti ragi roti (Jmwr2 dan Jmwr3), seperti alkohol, manis seperti gula, aroma seperti salak dan aroma seperti sari tebu segar. Beberapa isolat mengemisikan aroma seperti aroma inang dengan intensitas sangat lemah. Persistensi tes menunjukkan bahwa aroma tetap diemisikan jika di kultur dalam media PDA.

Kata kunci: senyawa volatile beraroma; mawar; mikroba; eksplorasi

\section{Pendahuluan}

Penelitian ini didasari dari pengalaman pribadi ketika mengisolasi bakteri dari ikan asin yang ternyata diperoleh bakteri yang beraroma seperti ikan asin (tidak dipublikasikan). Timbul dugaan bahwa kemungkinan aroma pada bunga, buah atau jenis bahan alam lain juga terkait dengan keberadaan mikroba didalamnya. Studi literatur menunjukkan bahwa mikroba dapat menghasilkan senyawa volatile (bebrapa macam yeas menghasilkan senyawa beraroma (Vandamme, et. al., 2003). Termasuk didalamnya adalah senyawa yang memberi aroma khas pada bunga, buah atau tumbuhan tertentu. Sebagai contoh, aroma seperti bunga mawar dihasilkan oleh Rodotorulla minuta (yeast) dengan volatile citronellal, aroma kacang almond oleh Ischenoderma benzoinum (jamur) dengan volatil benzaldehyde, aroma jeruk oleh Pseudomonas sp (bakteri) dengan volatil isopulegol sedang aroma apel dan nanas oleh Clostridium butyricum (bakteri) dengan volatil asam butirat, lihat Table 1, yang menyajikan senyawa volatile yang dihasilkan oleh mikroba dan zat kimia yang dihasilkannya (Gupta, et. al., 2015). 
Komponen minyak esensial tumbuhan terutama monoterpen, saesquiterpen, phenol dan alcohol (Lucchesi et. al., 2004), sedang monoterpen terbesarnya (Dhifi, et. al., 2016), misalnya minyal esensial dari Mawar Damascena (70\%), Rosa laba (41\%) dan Rosa klon 83661mencapai 51\% (Dobreva, et al., 2013). Produksi/emisinya berasosiasi dengan mikroba. Fumigasi terhadap bunga Sambucus nigra $L$ mengurangi emisi dan komposisi terpene bunga tersebut (Penuelas, et. al., 2014).

Tiap jenis mikroba menghasilkan senyawa volatil yang berbeda. Citronellol dan geraniol termasuk senyawa monoterpen yang dapat dihasilkan oleh yeast Kluiveromyces lactis, dan dengan mengontrol medium dan suhu kultur produksinya dapat ditingkatkan (Drawert and Barton, 1978). Senyawa volatil tersebut dapat berupa zat-zat yang menguntungkan, merugikan bahkan berbahaya bagi organism lain. Dilapornya senyawa volatile tertentu menjadi penanda keberadaan patogen tertentu (Sohrabi, et. al., 2014) yang dapat dideteksi dengan cepat menggunakan SEZI-MS (Zhu, et. al., 2010).

Banyaknya manfaat dari minyak volatil antara lain minyak mawar dan minyak sereh menciptakan pasar yang sangat besar dan terus meningkat dari tahun ke tahun. Atsiri dari mawar banyak digunakan sebagai parfum, kosmetik (antara lain cegah jerawat, antiaging, pelembab, penyeimbang kosmetik) dan dalam dunia kesehatan minyak mawar digunakan untuk aroma terapi, antivirus, anti bakteri pathogen dan antioxidant. Sedang minyak sereh banyak digunakan di dunia kesehatan sebagai anti jamur dan anti peradangan pada kulit (Boukhatem, et. al., 2014). Minyak atsiri dapat digunakan untuk mengurangi kontaminan udara rumah sakit karena bentuk gas lebih efektif dibanding dalam bentuk liquid, (Boukhatem, et. al., 2014). Minyak atsiri juga dapa digunakan untuk obat cacing (Xu, et. al., 2015), penyubur tanaman (Hofman, et. al., 2013; Maldau et. al, 2012), mempengaruhi pertumbuhan dan reaksi terhadap patogen (D, Alesso, et. al., 2014; Sharifi and Ryu, 2016) dan menghambat pertumbuhan Candida Albican (Madeira, et. a., 2016). Minyak ini juga punya prospek untuk meningkatkan kinerja mesin dengan menambahkan pada bahan bakar (Astuti dan Putra, 2014) dan punya potensi untuk digunakan sebagai bahan pengawet makanan (Ekpenyong and Akpan, 2017).

Dari uraian diatas, dapat difahami bahwa volatil dari mikroba punya nilai guna tersendiri tergantung dari VOCs yang dihasilkan. Setiap tahun permintaan pasar akan minyak sereh meningkat 3-
4\% dari berbagai Negara, sementara produksi dan kwalitas minyak atsiri Indonesia terus menurun.

Metode ekstraksi minyak atsiri secara tradisional banyak seperti penyulingan dan macerasi, adalah metode yang paling banyak digunakan secara global, namun karena proses pemanasan hasilnya tidak persis sama dengan aroma bahan segar, dan reproducibilitasnya kurang dapat dipastikan (Rassem et. al., 2016). Rendement yang diperoleh dengan mengekstraksi bahan tumbuhan sangat sedikit, sehingga penyulingan maupun ekstraksi dari tumbuhan memerlukan bahan baku yang sangat banyak untuk menghasilkan minyak yang sangat sedikit, misalnya atsiri dari mawar dihasilkan rendement sekitar dengan metode penyulingan didapatkan kisaran rendement $0.032-0.036 \%(\mathrm{w} / \mathrm{v})$ (Ahmad, et. al., 2009). Oleh karena itu, diperlukan lahan yang sangat luas untuk menanam tumbuhan mawar guna memenuhi permintaan pasar.

Kondisi alam dan penyakit yang mempengaruhi produksi bahan baku mempengaruhi stabilitas ketersediaan bahan baku tersebut, membuat ongkos produksi minyak atsiri menjadi sangat mahal sekitar US\$ 1000/kg. Sedangkan ongkos produksi VOCs menggunakan mikroba jauh lebih rendah dibanding dengan mengekstrak dari tumbuhan inangnya, yakni US\$ 5 (Lopez-Romero, et. al., 2015).

Minyak atisiri dari bahan alam tentunya tergantung dari jenis bahan. Disini hanya memaparkan minyak atsiri dari bunga mawar. Lebih dari $70 \%$ atsiri mawar tersusun atas monoterpen terutama geranio (Magnard, et. al., 2015), geraniol dan citronellol, nonadecane dan nerol (Dobreva, et. al., 2013). Geraniol $400 \square \mathrm{M}$ dapat menghambat $90 \%$ pertumbuhan sel cncer melalui penghambatan sintesis DNA/fase $\mathrm{S}$ pada pembelahan sel (Carnesecchi, et. al., 2001). Geraniol, komponen utama dari berbagai senyawa beraroma berperan sebagai insektisida, pest control, anti bakteri, anti oxidant, anti inflamasi; dan, geraniol ini dapat ditemukan pada tanamantanaman beraroma (Chen and Viljoen (2010).

Citronellol, sebagaimana geraniol; disamping aromanya yang membuat wangi mawar, senyawa ini juga mempunyai anti patogen yang kuat. Citronellol yang paling ampuh melawan E.coli dan Staphylococcus aureus, yakni dengan mengubah sifat permukaan sel pathogen seperti hydropobisitas dan muatan pada permukaan sel patogen; mempengaruhi integritas membrane dan kebocoran $\mathrm{K}+$ (Lopez-Romero et. al., 2015). Citronellol dan geraniol juga dapat disintesis oleh yast Kluyveromyces lactis (Drawert et. al., 1978), 
citronellol oleh Rodotula minuta (Gupta, et. al., 2017).

Dari uraian diatas, pada kesempatan ini peneliti ingin mengekplorasi kemungkinan untuk mendapatkan isolate mikroba beraroma dari bunga mawar dan bahan alam beraroma lain yang penulis belum menemukan publikasi tentang mikroba beraroroma yang diisolasi dari bahan alam tersebut.

\section{Metode}

\section{Isolasi Mikroba dari Bahan Alam}

Penelitian ini dilakukan pada bulan Julinovember 2018 di Laboratorium Pendidikan Biologi FKIP, Universitas mataram. Bahan atau sumber isolat adalah bunga mawar, bunga melati, bunga kamboja, batang sereh, buah kersen dan daun pandan. Bunga mawar diambil dari penduduk dekat botanical Garden, Narmada Lombok Barat. Sedang bahan lain dikumpulkan dari pasar local (Kebun roek dan Pasar perumnas, Mataram). Isolasi mikroba dilakukan tanpa sterilisasi untuk mengantisipasi adanya mikroba folosfer yang beraroma. Pemilihan bunga didasarkan pada puncak produksi aroma terjadi pada bunga yang baru saja mekar dari kuncup, yakni fase ke 4 perkembangan bunga (Guterman et. al, 2002). Satu gram bahan digerus menggunakan mortar dan pistil steril kemudian diencerkan dengan $1 \mathrm{ml}$ aquadest steril, supernatant $20 \mu \mathrm{L}$ ditebar pada medium PDA + anti bakteri untuk mendapatkan isolate jamur dan pada medium Nutrient Agar + anti jamur untuk mendapatkan isolate bakteri. Medium PDA yang telah diinokulasi kemudian diinkubasi pada suhu ruang selama 48 jam, dan medium NA diinkubasikan selama 24 jam pada pada suhu $30^{\circ} \mathrm{C}$. Individual koloni yang tumbuh dipindahkan ke medium baru, kemudian di lakukan panel test aroma untuk mengetahui jenis dan intensitas aroma secara kasar. Khusus untuk kersen, cairan buah diambil langsung $20 \mu \mathrm{L}$ dan ditebar pada medium.

\section{Test Aroma}

Test aroma untuk mengetahui kemampuan koloni dalam mengemisikan aroma yang paling mudah dilakukan adalah dengan menghirup udara sekitar petri. Hal ini aman dilakukan (Barkham; 2002). Kultur segar (24 jam inkubasi) dibuka penutupnya dan dibiarkan 4 manit dalam keadaan terbuka. Test dilakukan dengan menghirup udara sekitar petri maksimal $2 \mathrm{~cm}$ dari petri. Test ini dilakukan oleh 4 orang dan mencatat jenis aroma yang dihasilkan. Adapun kriteria intensitas aroma disajikan dalam Table 1. Aroma asli bahan alam diberikan score 20, dan diperkirakan maximal aroma yang didapat $1 / 4$ dari aroma asli. Metode ini memang belum sesuai metode standard untuk suatu produk industry, missal Method Sensory Evaluation (Mason and Nottingham, 2002).

Tabel 1. Skor dan Intensitas Aroma

\begin{tabular}{ll}
\hline skor & Intensitas aroma \\
\hline $1-2$ & Sangat lemah \\
3 & lemah \\
4 & sedang \\
5 & kuat \\
$>5$ & Sangat kuat \\
\hline
\end{tabular}

Sedangkan test dalam penelitian ini hanya sebagai langkah awal memilah bahwa aroma isolat bukan aroma busuk, jenis dan intensitas hanya iformasi kasar tentang isolate yang didaptkan.

\section{Hasil dan Pembahasan}

\section{Isolat yang diperoleh, Jenis dan intensitas aroma}

Isolat bakteri yang diperoleh dari medium dengan penambahan anti jamur, diamati 24 jam setelah inokulasi bakteri, atau 48 jamsetelah inokulasi untuk jamur. Koloni tunggal kemudian di pindahkan ke medium baru dan dinkubasi lagi selama 24 jam untuk bakteri atau 48 jam untuk jamur, dilanjutkan dengan test panel aroma dari 4 panelist.

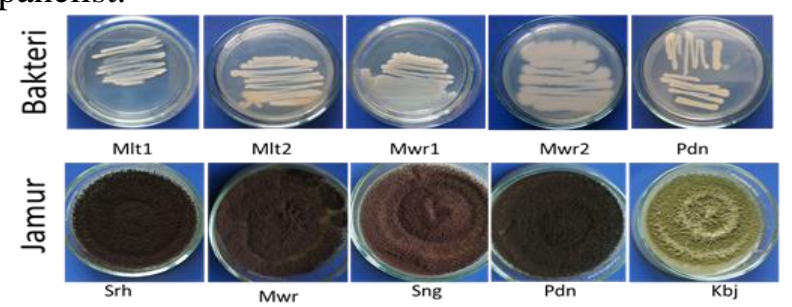

Gambar 5. Contoh gambar bakteri (atas) dan jamur (bawah) yang mengemisikan aroma (senyawa folatil). Keterangan:

Mlt = melati;

Mwr = mawar;

Pdn = pandan;

Srh = sereh;

$\mathrm{Kbj} \quad=$ Kamboja.

Angka dibelakang kode isolate menunjukkan nomor isolate.

\section{Isolat Bakteri}

Secara keseluruhan, isolat bakteri beraroma positif (+) diperoleh 12 isolat (Tabel 2), dengan aroma dan level aroma bervariasi, dari aroma yang tidak jelas, dan beberapa isolate yang beraroma sedikit seperti inangnya namun dengan intensitas 
yang jauh lebih rendah dan tercampur dengan aroma lain yang cukup sulit untuk mendisripsikannya. Namun demikian aroma tersebut positif. Isolat-isolat yang diperoleh beraroma sedap, segar, manis, seperti salak, seperti alcohol, seperti ragi roti, dan beberapa isolate yang mirip dengan aroma iangnya. Isolat yang beroma yang tidak sedap (busuk) tidak diperhitungkan.

Tabel 2. Sumber bahan dan banyaknya isolate yang diperoleh

\begin{tabular}{llll}
\hline No. & Sumber/bahan & bakteri & Jamur \\
\hline 1. & Bunga mawar & 3 & 3 \\
2. & Pelepah sereh & 2 & 1 \\
3. & Bunga Melati & 3 & 2 \\
4. & Bunga kamboja kuning & 1 & 1 \\
5. & Bunga cempaka & 0 & 1 \\
6. & Buah singapore & 0 & 5 \\
7. & Daun pandan & 3 & 2 \\
Total & & 12 & 14 \\
\hline
\end{tabular}

Jumlah isolate dan sumber (inang) dari isolat disajikan pada Tabel 3. Ditunjukkan dalam Table 3, bahwa, aroma mendekati mawar, sereh, melati, kamboja dan pandan didaptkan dari intensitas sangat lemah hingga sedang.

Tabel 3. Isolat Bakteri, Jenis dan Intensitas Aroma

\begin{tabular}{lll}
\hline Tabel & $\begin{array}{l}\text { Jenis aroma dan } \\
\text { Intensitas }\end{array}$ & Intensitas \\
\hline Jmwr1 & Blm jelas & Sangat lemah \\
Mwr2 & Mawar & Sangat lemah \\
Mwr3 & Mawar & Sangat lemah \\
Mlt1 & Melati & Lemah \\
Mlt2 & Melati & lemah \\
Mlt3 & Melati & Sangat lemah \\
Pdn1 & Pandan & Lemah \\
Pdn2 & Segar sari tebu, alcohol & Lemah \\
Pdn3 & Segar sari tebu, alcohol & Sangat lemah \\
Srh2 & Sereh & Lemah-sedang \\
Srh2 & Sereh & Sangat lemah \\
Kbj & kamboja & \\
\hline
\end{tabular}

Isolat bakteri Pdn2 dan Pdn3 memberi aroma yang khas lebih enak dibanding aroma isolate yang lain dan mempunyai intensitas aroma sedang, yakni aroma segar seperti tebu dan alcohol.

\section{Isolat Jamur}

Sebanyak 14 isolat jamur didapatkan dari bahan alam tersebut di atas dengan jenis aroma yang bervariasi dan tingkat aroma yang bervariasi. Hampir semua isolate mengemisikan aroma sedap/positif, namun sebagaimana pada isolate bakteri, intensitas aroma inang pada isolate sangat lemah hingga sedang. Kebanyakan isolate mengemisikan aroma campuran. Aroma ragi roti diperoleh 6 dari 14 isolat, aroma lakohol 2 dari 14 isolat, aroma Singapore didapatkan 6 dari 14 isolat. Sedangkan isolate yang mengemisikan aroma mirip aroma inangnya ditemukan 4 isolat dengan intensitas sangat lemah, yakni mawar, melati, sereh dan Singapore (Tabel 4). Aroma yang bervariasi jenis dan intensitasnya tersebut, terdapat isolateisolat yang mempunyai aroma enak/sedap lebih dari isolate yang lain (dicetak miring).

\section{Persistensi Test}

Percobaan persistensi aroma dilakukan dalam rangka melihat kemungkinan untuk apakah senyawa yang beraroma dieksresian ke luar medium yang dapat membuat medium cair menjadi beraroma?. Dalam percobaan ini hanya digunakan isolate jamur, berhubung isolate bakteri beraroma busuk dalam medium cair. Untuk itu isolate ditumbuhkan pada medium cair nutrient Broth (NB) pada suhu $30^{\circ} \mathrm{C}$ selama 24 jam untuk bakteri dan pada medium yeast malt (YM) suhu ruang selama 48 jam untuk jamur. Test panel aroma menunjukkan tidak tercium aroma sedap dari semua isolate jamur. Dari isolate bakteri tercium aroma busuk khas bakteri.

Tabel 4. Kode isolate, jenis dan intensitas aroma

\begin{tabular}{lll}
\hline $\begin{array}{l}\text { No/kode } \\
\text { isolat }\end{array}$ & Jenis aroma & $\begin{array}{l}\text { Intensitas } \\
\text { Aroma }\end{array}$ \\
\hline $\begin{array}{l}\text { 1. Jmwr1 } \\
\text { 2. Jmwr2 } \\
\text { 3. Jmwr3 }\end{array}$ & $\begin{array}{l}\text { Mawar, } \\
\text { Mawar, } \\
\text { enak, }\end{array}$ & $\begin{array}{l}\text { sangat lemah } \\
\text { lemah-sedang } \\
\text { Sedang }\end{array}$ \\
4. Jmlt1 & Melati, & Lemah \\
5. Jsrh & Sereh, & lemah-sedang \\
6. Jpdn1 & Pandan, & sangat lemah \\
7. Jpdn2 & Salak, manis, & Sedang \\
8. Jkbj & $\begin{array}{l}\text { Kamboja, ragi roti, } \\
\text { 9. Jcmp }\end{array}$ & $\begin{array}{l}\text { Salak, ragi roti, } \\
\text { lemah-sedang } \\
\text { lemah-sedang }\end{array}$ \\
10. Jsng1 & $\begin{array}{l}\text { Salak, ragi roti, } \\
\text { singapore, }\end{array}$ & lemah-sedang \\
11. Jsng2 & Salak, ragiroti, alkohol, & Sedang \\
& $\begin{array}{l}\text { singapore, } \\
\text { 12. Jsng3 }\end{array}$ & $\begin{array}{l}\text { Singapore, } \\
\text { Ragi roti, singapore }\end{array}$ \\
13. Jsng4 & $\begin{array}{l}\text { Singapore, alkohol, } \\
\text { 14. Jsng5 }\end{array}$ & $\begin{array}{l}\text { lemah-sedang } \\
\text { lemah-sedang }\end{array}$ \\
\hline
\end{tabular}

Hasil panel jenis aroma dan intensitasnya menunjukkan bahwa aroma yang diemisikan oleh isolate-isolat yang didpatkan dari bahan alam, bervariasi. Dari segi jenis aroma tidak selalu mengemisikan aroma seperti aroma inangnya, meskipun ditemukan isolate yang mirip dengan aorma inangnya dengan intensitas yang sangat 
lemah. Aroma yang diemisikan dari isolate-isolat tersebut aroma ragi roti, alcohol, manis, aroma salak, dan aroma tebu. Intensitas aroma yang diemisikan hanya berkisar sangat lemah hingga sedang (skor 4 dari aroma kuat skor 5). Sedang aroma aslinya diberi skor 20 .

Fenomena berbeda aroma dari aroma inang dan rendahnya intensitas aroma ini kemungkinan bahwa dalam proses produksi aroma dalam tumbuhan inangnya, misalnya pada bunga mawar, ada keterlibatan dari inang. Gen-gen yang diisolasi dari tanaman mawar seperti gen ODORANT1 ikut mengatur sitesis fragrant/aroma pada bunga petunia (Verdonk, et. al., 2005), gen OOMT1 - OOMT4 pada bunga mawar (Scalliet, et. al, 2002) dan gen shNUDX1 pada bunga mawar (Magnard, et. al., 2015) terexpresi bersamaan dengan emisi aroma. Meskipun hasil analysis dari 200 senyawa, tidak satupun merupakan hasil emisi dari mikroba tunggal (Wang, et. al., 2016). Namun pertanyaan besar apakah gen tersebut benar-benar berasal dari tanaman mawar ataukah terisolasi dari bakteri yang terdapat pada bunga mawar, mengingat bahwa setiap tanaman biasanya megandung mikroba baik sebagai mikroba endofit ataupun filosfer. Selanjutnya (Gupta, et. al., 2015) melaporkan bahwa mikroba secara individu mampu menghasilkan senyawa folatil yang beraroma khas bunga, buah atau bagian lain dari inang. Sebagai contoh aroma sperti mawar diemisikan oleh yeast Rodotorulla minuta dengan senyawa citronellal, aroma kacang almond oleh fungi Ischnoderma benzoinum dengan senyawa benzaldehyde dan aroma coklat diemisikan oleh yeast kluyveromyces $s p$ dengan senyawa Thaumatin dan monellin (Gupta, et. al., 2015). Keberadaan senyawa volatile dapat digunakan untuk mendeteksi infeksi mikroba tertentu. (Sahrabi, et. al, 2017). Dengan demikian bahwa mikroba juga terlibat dalam dan bahkan menghasilkan senyawa beraroma sendiri.

Hasil penelitian ini sejalan dengan Gupta, et. al., (2015) dan Sharobi, et. al., (2017). Aaroma yang paling sering didapatkan adalah aroma ragi roti, namun aroma segar seperti salak manis dan tebu juga dapat ditemukan. Masih tercium aroma pada subkultur murni mengidikasikan bahwa isolate-isolat tersebut membawa gen yang terlibat dalam biosintesis aroma (lihat, Table 4) meskipun dengan aroma yang tidak sama persis dengan aroma inang dan dengan intensitas sangat lemah hingga sedang. Dengan demikian dapat dikatakan bahwa adalah mungkin untuk mendapatkan isolate mikroba yang diisolasi dari bahan alam yang beraroma seperti inangnya dan menunjukkan bahwa aroma yang didapatkan tidak selalu mirip aroma inang, namun sedap atau positif.

Perisistensi dari aroma tidak bertahan lama, setelah kultur kedua dalam medium cair, test panel tidak menunjukkan bahwa aroma yang sebelumnya diemisikan. Keterlibatan gen-gen/enzim-enzim inang mungkin diperlukan. Dugaan sementara mungkin karena substratnya tidak tersedia. Kelompok peneliti kemudian mencoba untuk memberikan substrat extrak tebu /sari tebu atau sari tebu diperkaya yeast ekstrak dan garam. Dipilihnya tebu sebagai medium jamur karena sari tebu memiliki nutrisi yang lebih lengkap dibanding dengan hanya menabahkan gula. Penambahan sari tebu dengan ekspektasi bahwa isolate akan mensintesis senyawa folatil. Sari tebu diperoleh dari pedagang sari tebu di jln Arya Banjar Getas Mataram. Masing-masing isolate jamur ( 8 isolat) diiokulasikan ke dalam $8 \mathrm{ml}$ medium 1 (sari tebu) atau medium 2 (sari tebu ditambahkan yeast $2 \%$ yeast ekstrak dan $5 \mathrm{gr} / \mathrm{L} \mathrm{NaCl}$ ). Dalam percobaan ini digunakan $20 \mathrm{ml}$ tabung reaksi, dan diinkubasikan pada suhu ruang selama 48 dan dilakukan dalam duplo. Setelah 48 jam setelah inokulasi, hasil percobaan menunjukkan bahwa semua tabung reaksi mengemisikan aroma sari tebu, seperti aroma mediumnya, namun dengan intensitas aroma lebih kuat dari medium tanpa isolat.

Aroma sari tebu yang lebih kuat dibanding aroma mediumnya menunjukkan bahwa ada kemungkinan isolate tersebut masih mempunyai kemampuan dalam mensintesis dan mengemisikan senyawa volatile. Dari hasil tersebut peneliti berspekulasi kemungkinan jamur yang bermycelium tersebut memerlukan udara yang lebih untuk tumbuh dan mengemisikan aroma. Dengan demikian, peneliti melanjutkan penelitian dengan menumbuhkan jamur pada medium PDA dalam cawan petri sehingga jamur dapat tumbuh leluasa. Hasil percobaan menunjukkan bahwa dalam medium PDA jamur mengemisikan kembali aroma yang ada sebelumnya. Dengan demikian dapat dikatakan bahwa isolate-isolat tersebut mempunyai persistensi dalam mengemisikan aroma sedap.

Temuan ini membuka diskusi baru bagaimana meningkatkan intensitas yang aroma dan bagaimana memperoleh jenis aroma yang diinginkan. Memodifikasi media dengan peningkatan suplay carbon dan nitrogen dapat meningkatkan senyawa volatil (Hosoglu, 2018). Dalam penelitian ini belum ditemukan formula yang tepat untuk meningkatkan aroma dan atau menentukan aroma yang diinginkan. Pendekata Rekayasa genetik untuk menghasilkan senyawa 
volaltil dapat pula dilakukan terhadap tanaman terkait, terhadap isolate yang ditemukan ataupun menggunakan mikroba model. Rekayasa terhadap tanaman terkait lebih dapat diyakinkan bahwa substrat serta gen-gen atau enzim-enzim yang terlibat dalam penyusunan senyawa folatil beraroma tersedia pada tanaman tersebut.

Aroma harum mawar membuat banyak peneliti memfokuskan pada tanaman ini. Senyawa volatil utama $(>70 \%)$ yang menyusun aroma pada bunga mawar adalah monoterpe terutama geraniol. Monoterpen pada umumnya disintesis di chloroplast. Namun telah ditemukan gen RhNUDXI yang terekspresi di sitoplasa, mawar mengemisikan senyawa volatil mengekspreiskan gen ini sebaliknya mawar yang tidak mengemisikan aroma wangi tidak mengekspresikan gen ini (Magnard et. $a l, 2015)$. Gen lain yang juga terekspresikan hanya pada bunga yang beraroma antara lain keluarga gen Orcinol Omtehyltransferase OOMT1, OOMT2, OOMT3 dan OOMT4 (Scalliet et. al, 2004). Sedang factor transkripsiODORANT1 merupakan kunci pengaturan pembentukan senyawa volatil melalui jalur sikimat pada bunga petunia (Verdonk et. al, 2005). Masih banyak lagi gen-gen yang merupakan pengatur bagiterbentuknya senyawa volatil yang mempengaruhi aroma pada bunga atau pada bagian tanaman tertentu. Dengan demikian, gen RhNUDX1, gen ODORANT1 dan OOMT1-OOMT4 merupakan beberapa dari banyak kandidat yang menarik untuk dicoba untuk rekayasa genetik pada mawar, terutama gen RhNUDX1.

Untuk rekayasa genetika pada mikroba, gengen tersebut juga menarik untuk dicoba kemudian lihat apa yang terjadi, mengingat bahwa pada awal diisolasi isolate-isolat tersebut masih mampu mengemisikan senyawa volatil dengan aroma emisi sedap/positif.

\section{Kesimpulan}

Telah didapatkan 12 isolat bakteri dan 14 isolat jamur yang mamupu menghasilkan aroma sedap dari bahan alam: 3 isolat bakteri dan 3 isolat jamur dari bunga mawar; 2 isolat bakteri dan 1 isolat jamur dar pelepah sereh; 3 isolat bakteri dan 3 isolat jamur dari bunga melati; satu isolate jamur dari bunga cempaka; 1 isolat bakteri dan 1 isolat jamur dari bunga kamboja kuning; 5 isolat jamur dari buah Singapore matang dan 3 isolat bakteri dan 2 isolat jamur dari daun Pandan. Adapun intensitas dan aroma bervariasi, namun semuanya sedap.

\section{Ucapan Terimakasih}

Penelitian ini dibiayai dari DNA PNBP Universitas Matara 2017/2018. Terimaksih kepada PNBP Universitas Mataram. Terima kasih juga kepada Dra. Dewa Ayu Citra Rasmi, M.Si (anggota 1) yang telah melakukan isolasi baketri dan jamur dari bahan alam dan Dr. Syamsul Bahri, M.Si (anggota 2) yang telah menyediakan bahan-bahan alam dan medium kultur untuk isolasi.

\section{Daftar Pustaka}

Ahmad, D., Sahoo, D , Ahmad, J. and Tandon, S. 2009. GC-MS Composition of Rose Oil (Rosa damascena) of Different Agro Climatic Regions of North India. Asian Journal of Chemistry, 21 (6), 4643-4647, dilihat april 2018. http://www.asianjournalofchemistry.co.in

Astuti, W. dan Putra, N.N. 2014. Peningkatan kadar geraniol dalam minyak sereh wangi dan aplikasinya sebagai bio additive gasoline. Jurnal Bahan Alam Terbarukan, 3(1), 2014. Dilihat April 2018. http://web.journal.unnes.ac.id/

Barkham, T. (2002). Sniffing Bacterial Cultures on Agar Plates: a Useful Tool or a Safety Hazard? J Clin Microbiol. 2002. doi: 10.1128/JCM.40.10.3877.2002

Bota, W., Supono, M. dan Rondonuwu, F.S. 2015. Potensi Senyawa Minyak Sereh Wangi (Citronellol Oil) dari Tumbuhan Cymbopogon nardus L. Sebagai Agent Anti Bakteri. Proceding Seminar Nasional Sains dan Teknologi Fakultas Teknik Universitas Muhammadiyah Jakarta. Diakses: https://jurnal.umj.ac.id/index.php/semnast ek/article/view/548/514

Boukhatem, MN; Ferhat, MA; Kameli A; Saidi F and Kebir HT (2014). Lemon grass (Cymbopogon citratus) essential oil as a potent anti-inflammatory and antifungal drugs. Libyan $J$ Med, 9, doi: 10.3402/ljm.v9.2543

Carnesecchi, S., Schneider, J., Ceraline, B., Duranton, F., Gosse, N. S., Raul, F., 2001. Geraniol, a component of plant essential oils, inhibits growth and polyamine biosynthesis in human colon cancer cells. The Journal of 
pharmocology and experimental therapeutics. 301(2), 625-630.

doi: 10.1124/ipet.301.2.625

Chen and Biljoen, 2010. Geraniol, A review of a commercially important fragrance material. South African Journal of Botany. 76(4): 643-651.

https://www.sciencedirect.com

D'Alessandro, M., Erb, M., Ton, J., ${ }^{3}$ Brandenburg, A, Karlen D, Zopfi, J. and Turlings, T.C.J. 2014. Volatiles produced by soil-borne endophytic bacteria increase plant pathogen resistance and affect tritrophic interactions. Plant, Cell and Environment 37: 813-826. doi: 10.1111/pce. 12220

De Oliveira,W,A,, Pereira, F.D.O., Luna, G.C.D.G.D, Lima, I.O., Wanderley, P.A., Lima, B.D. and Lima, E. 2011. Antifungal activity of Cymbopogon winterianusjowitt ex bor against Candida albicans. 42(2), 433-44. https://www.ncbi.nlm.nih.gov. doi: 10.1590/S1517-83822011000200004

Dobreva, A. Velcheva, A. Bardarova, V and Bardarov, K. 2013. Chemical composition of different genotypes oil bearing roses. Bulg. J. Agric. $\quad$ Sci., $\quad 19, \quad 1213-1218$. https://www.agrojournal.org/

Dhifi, W., Bellili, S., Sabrine, J., B and Wissem M., Nahar, L. 2016. Essential Oils' Chemical Characterization and Investigation of Some Biological Activities: A Critical Review. Medicines (Basel). 3(4), 25. doi: 10.3390/medicines3040025

Drawert, F. and Barton, H. 1978. Biosynthesis of flavor compounds by microorganisms. 3 . Production of monoterpenes by the yeast Kluyveromyces lactis, J, Agric, Food Chem, 26 (3),765-766. doi: $10.1021 / \mathrm{jf} 60217 \mathrm{a} 029$

Ekpenyong, C.E, Akpan EE, 2017. Use of Cymbopogon citratus essential oil in food preservation: Recent advances and future perspectives. Crit Rev Food Sci Nutr. 57(12), 2541-2559.

doi: 10.1080/10408398.2015.1016140.

Guterman, I., Shalit, M., Mend, N., Piestun D., Dafny-Yelin, M., Shalev, G., Bar, E., Davydov, O., Ovadis, M., Emanuel, M., Wang, J., Adam, Z., Pichersky, E., Lewinsohn, E., Zamir, D., Vainstein, A., and Weiss, D. 2002. Rose Scent, Genomics Approach to Discovering
Novel Floral Fragrance-Related Genes. The Plant Cell, Vol. 14, 2325-2338. doi: ttps://doi.org/10.1105/tpc.005207

Hofmann, N.R. 2013. Volatile Organic Compounds: A Bacterial Contribution to Plant Sulfur Nutrition. The Plant Cell, Vol. 25: 238. doi:https://doi.org/10.1105/tpc.113.25071 $\underline{2}$

Lima, A., Pérez A., Sous,a J.P., Pinheiro, L.S, Oliveira-Filho A.A., Siqueira-Júnir J.P., Lima, E.O. 2017. Antifungal Activity of Geraniol on Candida albicans Isolates of Pediatric Clinical Importance. International Journal of Pharmacognosy and Phytochemical Research 9(4), 581586. doi: 10.25258/phyto.v9i2.8131

Lopez-Romero, J.C., González-Ríos, H., Borges, A. and Simõe, M. 2015. Antibacterial Effects and Mode of Action of Selected Essential Oils Components against Escherichia oli and Staphyloco-ccus aureus. EvidenceBased Complementary and Alternative Medicine. Article ID 795435, 9 pages. doi.org/10.1155/2015/795435

Lucches, E., F., Chemat, J., Smadja. 2004. An original solvent free microwave extraction of essential oils from spices. Flavour Fragr. Journal, 19: 134-138. https://onlinelibrary.wiley.com/doi/abs/10 .1002/ffj.1274

Madeira., P.L.B., Letícia, T., Carvalho, Marco A, B, Paschoal, duardo M, de Sousa, Eduardo B. Moffa, Marcos A, dos Santos da Silva, Rudys, de, Jesus, Rodolfo Tavarez and Letícia M, Gonçalves, 2016. In vitro Effects of Lemongrass Extract on Candida albicans Biofilms, Human Cells Viability, and Denture Surface. Front. Cell. Infect. Microbiol. Vol. 6. doi.org/10.3389/fcimb.2016.00071

Magnard, J.L., Roccia, A., Caissard, J.C., Vergne, P., Sun, P., Hecquet, R, Dubois, A., Hibrand-Saint, O.L., Jullien, F., Nicolè, F., Raymond, O., Huguet, S., Baltenweck, R, Meyer, S., Claudel, P., Jeauffre, J., Rohmer, M., Foucher, F., Hugueney, P., Bendahmane, M. and Baudino, S. 2015. Plant Volatiles Biosynthesis of monoterpene scent compounds in roses. Science. 349 (6243):81-3. doi: 10.1126/science.aab0696

Maldau, D.G., Meldau, S., Hoang, L.H., Underberg, S., Wünsche, H., Baldwin, I.T. 
2013. Dimethyl disulfide produced by the naturallyassociated bacterium Bacillus sp. B55 promotes Nicotiana attenuata growth by enhancing sulfur nutrition. Plant Cell. 25, 2731-2747.

https://www.ncbi.nlm.nih.gov/pubmed/26 138978

Mason, R. L., and Nottingham, S. M. 2002. Sensory evaluation manual. Phitsanulok, Thailand: Naresuan University.

Mohamed, B.A.A., Nancy, R., Hofmann. 2013. Volatile Organic Compounds: A Bacterial Contribution to Plant Sulfur Nutrition. Plant Cell. 25(7), 2381. doi: $10.1105 / \mathrm{tpc} .113 .250712$.

Peñuelas, J., Farell-Armengol, G., Lusia, J., Gargallo-Garriga, A., Rico, L, Sardan, S., Fillella, I. and Terradas, J. 20114. Removal of floral microbiota reduces floral terpene emissions. Scientific Reports, 4(6727). doi: 10.1038/srep06727

Rassem, H., H., A., Nour, A., H., Yunus, R., M., 2016. Techniques for Extraction of Essential Oils from Plants: A Review. Plant Australian. Diakses. http://www.asianjournalofchemistry.co.in/

Scalliet, G, Journot, N, Jullien, F, Baudino, S, Magnard, J., L., Channelière, S., Vergne, P., Dumas, C., Bendahmane, M., Cock, J.,M. and Hugueney, P. 2002 Biosynthesis of the Major Scent Components 3,5Dimethoxytoluene and 1,3,5Trimethoxybenzene by Novel Rose OMethyltransferases. FEBS Letters, 523, 113-118.

https://www.ncbi.nlm.nih.gov/pubmed

Sharifi, R. and Ryu, Choong-Min. 2016. Are Bacterial Volatile Compounds Poisonous Odors to a Fungal Pathogen Botrytis cinerea, Alarm Signals to Arabidopsis Seedlings for Eliciting Induced Resistance, or Both? Front. Microbio. doi. https://doi.org/10.3389

Sohrabi, M., Zhang, L., Zhang, K., Ahmetagic A and Wei, M. Q. 2017. Volatile Organic Compounds as Novel Markers for the Detection of Bacterial Infections. Clinical Microbiology: https://www.omicsonline.org/

Tajidin, N., E., Ahmad, S., H., Rosenani, A. B., Azimah, H., and Munirah, M. 2012. Chemical composition and citral content in lemongrass (Cymbopogon citratus) essential oil at three maturity stages.
African Journal of Biotechnology, 11(11), pp. 2685-2693.

https://www.tandfonline.com/doi/.../1040 $\underline{8398.2018 .143753}$

Vandamme, E., J, 2003. Bioflavours and fragrances via fungi and their enzymes. Fungal Diversity 13: 153-166. https://onlinelibrary.wiley.com/doi/abs/10 $.1002 /$ jctb. 722

Verdonk, J.C., Haring, M.A., van Tunen, A. and Schuurink, R,C. 2005. DORANTI Regulates Fragrance Biosynthesis in Petunia Flowers. FEMS Microbiology Reviews, 39(2), 222-233. https://www.ncbi.nlm.nih.gov/

Xu, Y., Lu, H., Wang, X., Zhang, K.Q. and Li. G.H. 2015. Effect of Volatile Organic Compounds from Bacteria on Nematodes. Chemostry and Biodiversity Research Article. Doi: $10.1002 / c b d v .201400342$

Zhu, J., Bean, H.D., Kuo, Y.M. and Hill, J.E., 2010. Fast Detection of Volatile Organic Compounds from Bacterial Cultures by Secondary Electrospray Ionization-Mass Spectrometry. J. Clin. Microbiol. 48 (12), 4426-4431. doi: 10.1128/JCM.00392-10 